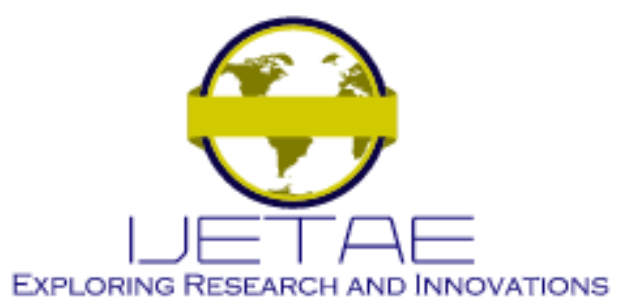

International Journal of Emerging Technology and Advanced Engineering

Website: www.ijetae.com (E-ISSN 2250-2459, Scopus Indexed, ISO 9001:2008 Certified Journal, Volume 11, Issue 08, August 2021)

\title{
Development of Water Quality Control and Monitoring Systems for Hydroponic Plants Based on the Embedded Web
}

\author{
Rony Baskoro Lukito ${ }^{1}$, Cahya Lukito $^{2}$ \\ ${ }^{1,2}$ Computer Science, Bina Nusantara University, Jakarta, 11480, Indonesia
}

\begin{abstract}
Hydroponics is a farming technology using water mixed with mineral nutrients which is continuously flowed to the roots of plants for 24 hours every day. The height of the water reserves, the water temperature, the nutrient content of the water and the $\mathrm{pH}$ of the water are some of the factors that need to be considered in planting crops using the hydroponic method. Regular observations and control functions of water quality are very important to ensure hydroponic plants can grow well. The function of controlling and observing water quality can be accomplished by developing a hardware system with an embedded Web equipped with a dosing-pump module to determine water quality based on the calculation of input data from the water quality sensor. With the embedded Web application, the control and observation functions can also be carried out remotely and periodically the hydroponic system can report the current state directly via the TCP/IP network. In this study, a second generation minimum system model will be developed which is the result of improvements from previous research. Water $\mathbf{p H}$ and water conductivity (EC) sensors can be activated simultaneously. The addition of a dosing-pump module is used to provide a liquid to adjust the $\mathrm{pH}$ value of water and plant nutrient fluids, while the addition of an embedded Web application to a Wi-Fi hardware module is to improve the ease of control and monitoring functions.
\end{abstract}

Keywords-Embedded Web, Hydroponic water quality, Remote control and monitoring

\section{INTRODUCTION}

The method of farming using water media is very suitable for application on narrow land such as in cities or houses with limited yards. To meet the nutritional needs of plants, water that has been mixed with mineral nutrients needed by plants is continuously flowed to the plant roots for 24 hours every day. Water temperature, water level, water conductivity and water $\mathrm{pH}$ need to be observed to determine the actions required for hydroponic plants to grow properly.
Most of the urban residents work in offices and have high mobility. With the routine work in the office and the limited time they have, the problem is that they are less able to monitor hydroponics all the time. Then the remote control and observation functions can provide enormous benefits. Monitoring and control of water quality for hydroponic plants can be done remotely and can be accessed at any time via a TCP / IP-based network.

This research requires several hardware modules, namely: Arduino open hardware single board microcontroller, water $\mathrm{pH}$ sensor, water conductivity (EC) sensor, water temperature sensor and water level sensor. Arduino open hardware single board microcontroller is a minimum system equipped with a microcontroller that can be used as a basis for developing application programs to process data from sensors and control the $\mathrm{pH} / \mathrm{EC}$ dosingpump in determining water quality according to the needs of hydroponic plants. This module will be equipped with a Wi$\mathrm{Fi}$ hardware module for the development of an embedded WEB based application.

\section{OBJECTIVES AND BENEFITS}

In previous research, a water quality observation system has been successfully established, but water $\mathrm{pH}$ observations cannot be carried out simultaneously with water conductivity observations. Based on input during the presentation at the 2018 Telkomnika ICW seminar [1], this research will make improvements to the hardware module of the $\mathrm{pH}$ sensor and water conductivity sensor so that observations can be made simultaneously. A control function is also added to adjust water quality according to the needs of hydroponic plants. The Wi-Fi module is added to build an embedded WEB application so that the control system and water quality observation for hydroponic plants can be done remotely using a TCP/IP network. 


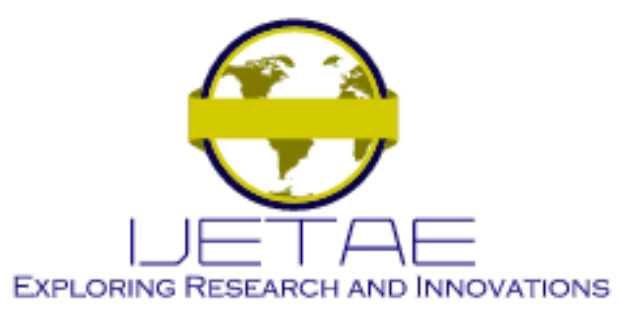

International Journal of Emerging Technology and Advanced Engineering

Website: www.ijetae.com (E-ISSN 2250-2459, Scopus Indexed, ISO 9001:2008 Certified Journal, Volume 11, Issue 08, August 2021)

By developing a supporting device for a hydroponic planting system that can be applied in a residential environment, it is hoped that this can help increase the food security of each family. This research roadmap aims to improve food security at the family level. There are four main components of food security [2]-[4], namely:

\section{Food Availability}

The ability to meet the basic needs of sustainable food.

\section{Food access}

The ability to have nutritious food resources economically and physically.

\section{Use of Food}

The ability to use the right and right to utilize food ingredients.

\section{Stability}

To be food secure, a population, household or individual must always have access to sufficient food. Therefore, the concept of stability refers to the availability and access dimensions of food security.

\section{LITERATURE REVIEW}

\section{A. Hydroponic Technology}

With a hydroponic system, plants can grow without using soil media. Water that has been mixed with mineral nutrients needed by plants is placed in a reservoir, then the water is drained to the plant roots with the help of a water pump. By utilizing the force of gravity, this water will flow by itself to the water reservoir through a predetermined pipeline. In addition to maintaining the height, flow and temperature of water, $\mathrm{pH}$ and $\mathrm{EC}$ of water are very important to always be observed and controlled, plants will lose the ability to absorb the nutrients needed if the $\mathrm{pH}$ value of the water does not match the characteristics of the plant.

The following are some of the hydroponic system techniques currently available [5], [6]: Deep Water Culture, Nutrient Film Technique, Aeroponic, EBB and Flow and Drip System.

Farming using a hydroponic system will have many advantages. With good water management, the plants will grow bigger and faster than the planting system using soil media. The utilization of water also becomes more efficient by using a rotating system. Thus the hydroponic system is more environmentally friendly, cleaner and healthier in an effort to increase food security.

\section{B. Arduino Minimum System}

Arduino is defined as a minimum system that is Open Source for Hardware or Software [7]. The Arduino board can read input from analog or digital sensors, press buttons, to receive information via a computer network which is then processed into an output with the support of a microprocessor on the board. Arduino also provides supporting software to make software applications easier, namely by providing the Arduino programming IDE and the Arduino Software library [8].

Temperature Sensor Module: A DS18B20 waterproof temperature sensor [9] is used to measure the temperature of the water in the water reservoir of a hydroponic system. This sensor can be used in environments up to a temperature of 125 degrees and has a digital output (9-12 bits) which can be programmed according to accuracy needs. Communication with this module is enough by using an interface cable with a voltage reference of 3 - 5 volts DC. The following are more detailed specifications of the temperature sensor:

- Voltage range $3.0 \mathrm{~V}-5.5 \mathrm{~V}$ for power or data

- Accuracy of $\pm 0.5^{\circ} \mathrm{C}$ for temperature range $-10^{\circ} \mathrm{C}$ to $+85^{\circ} \mathrm{C}$

- Temperature measurement range: -55 to $125^{\circ} \mathrm{C}\left(-67^{\circ}\right.$ $\mathrm{F}$ to $+257^{\circ} \mathrm{F}$ )

- Unique 64 bit ID. Many sensors can use a single wire bus

- Has Temperature-limit alarm system

- Query time is less than 750ms

pH Sensor Module: DFRobot has two types of $\mathrm{pH}$ sensors, namely low cost and industrial probes. In this study, a low cost pH meter probe SKU: SEN0161 [10] was used as a first step to identify problems in building a remote observation system for hydroponic systems. The following below is a more detailed specification of the $\mathrm{pH}$ sensor:

- Working Voltage: $5.00 \mathrm{~V}$

- $\mathrm{pH}$ measurement range: 0-14

- Range of use in temperature range: $0-60^{\circ} \mathrm{C}$

- Accuracy: $\pm 0.1 \mathrm{pH}\left(25^{\circ} \mathrm{C}\right)$

- Response Time of measurement: $\leqslant 1 \mathrm{~min}$

- BNC Connector Interface

- Equipped with a Gain Adjustment Potentiometer and an LED Power Indicator

Conductivity Sensor Module: A conductivity sensor is needed to measure the levels of nutrients in the water that will be absorbed by plant roots from the hydroponic system. 


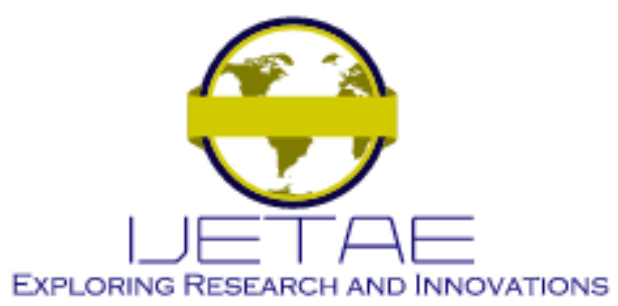

International Journal of Emerging Technology and Advanced Engineering

Website: www.ijetae.com (E-ISSN 2250-2459, Scopus Indexed, ISO 9001:2008 Certified Journal, Volume 11, Issue 08, August 2021)

Conductivity is the ability of a medium to pass an electric current. Measurement of water conductivity represents the content of nutrients (electrolytes) dissolved in water. The size of the water conductivity required varies according to the type of plant to be planted. The following is a detailed specification of the water conductivity sensor used in the study [11].

- Working Voltage: $+5.00 \mathrm{~V}$

- Measuring range: $1 \mathrm{~ms} / \mathrm{cm}-20 \mathrm{~ms} / \mathrm{cm}$

- Range of use in temperature range: $5-40^{\circ} \mathrm{C}$

- Accuracy: $< \pm 10 \%$ F.S

- Electrode cable length: $60 \mathrm{~cm}$

- BNC Connector Interface

- Equipped with an LED Power Indicator

Water Level Sensor Module: The water level sensor is needed to determine the water reserves in the water storage area of the hydroponic system. The workings of the HCSR40 ultrasonic distance sensor is by measuring the travel time required by the sound to bounce off the object in front of the sensor. The following is a detailed specification of the HC-SR04 ultrasonic distance sensor which is used to detect the water level used in the study [12], [13]:

- Voltage: 5 Volt

- Static Current: $<5 \mathrm{~mA}$

- Output Level: 5V - 0V

- Sensor Angle: $<15$ degrees

- Measuring range: $2 \mathrm{~cm}-450 \mathrm{~cm}$

\section{Results on previous research}

In previous research, it was concluded that the $\mathrm{pH}$ sensor cannot be run simultaneously with the conductivity sensor [1]. This is due to the current flowing from the conductivity sensor module through the water on the $\mathrm{pH}$ sensor module. As shown in Figure 1 are the results of observations in previous research, it appears that when the conductivity sensor is activated, a spike appears in the $\mathrm{pH}$ measurement results and the value jumps quite large in the next second, resulting in inaccurate $\mathrm{pH}$ and conductivity measurements.

From the results of literature studies, consultations and suggestions obtained during the presentation at the 2018 Telkomnika ICW seminar [1], these problems can be overcome by 2 methods. The first method is to make an active water $\mathrm{pH}$ sensor alternately with a water conductivity sensor. Meanwhile, the second method is to add an isolator module to the input / output intermediate module of the sensor to prevent electrical interference.
By using the second method, it is hoped that these problems can be resolved and the research can be carried out in accordance with the next research roadmap.

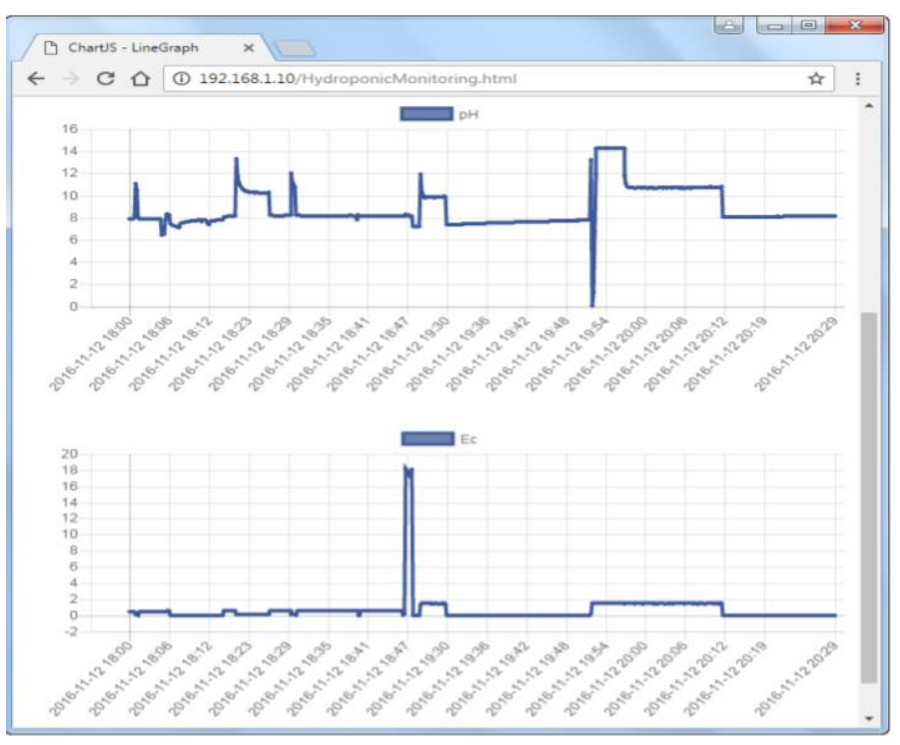

Figure 1: Problems with $\mathrm{pH}$ measurement results together with EC measurements

\section{RESEARCH METHODS}

The research methodology is the stages of research that must be determined before carrying out research, so that research can be carried out in a directed, clear, efficient and effective manner. The following is a research flowchart that illustrates what will be done in this research.

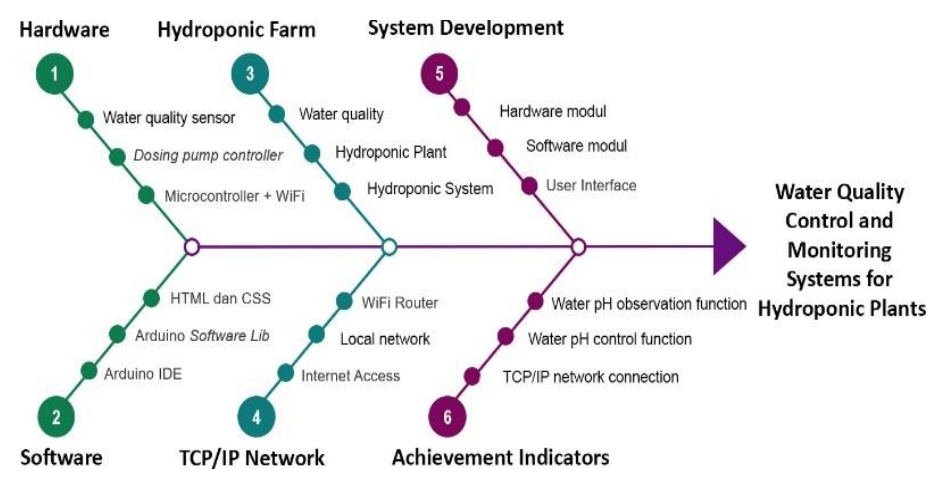

Figure 2: Research fish bone 


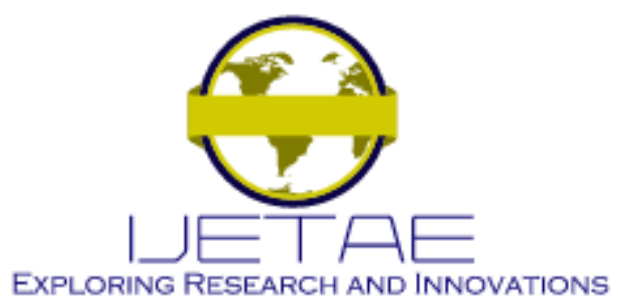

International Journal of Emerging Technology and Advanced Engineering

Website: www.ijetae.com (E-ISSN 2250-2459, Scopus Indexed, ISO 9001:2008 Certified Journal, Volume 11, Issue 08, August 2021)

\section{A. System Design}

To build a hydroponic plant observation and control system, several hardware and software modules are needed as follows:

- Hardware module sensor water $\mathrm{pH}$, water conductivity, water level, water temperature and air temperature.

- Hardware module driving dossing pump liquid pH Up, $\mathrm{pH}$ Down, nutrient $\mathrm{A}$ and nutrient $\mathrm{B}$ for hydroponic plants.

- Relay control hardware module

- A microcontroller hardware module equipped with a Wi-Fi module

- Computer Networks

- Arduino open software library

- Arduino Programming Tool

\section{B. Research Stages}

In this research, the second generation of hardware and software will be built which is a refinement of the results of previous research, with the following research stages:

- Collecting data and information related to hardware modules and supporting library software.

- Build hardware using hardware modules that can still be used from previous research and add new hardware modules to increase the capabilities of the new system.

- Develop modular software for each hardware module that has been running well functionally.

- Building a WEB-based User Interface

- The results of the development of the hardware and software modules are then applied to a hydroponic planting trial system in a computer network equipped with kale or mustard greens.

\section{System Development}

Hardware and software development in this study uses the Waterfall Model which is a classic model that is systematic and sequential. The Waterfall Model has 5 stages in development: Communication, Planning, Modeling, Construction and Deployment as shown in Figure 5 [14]

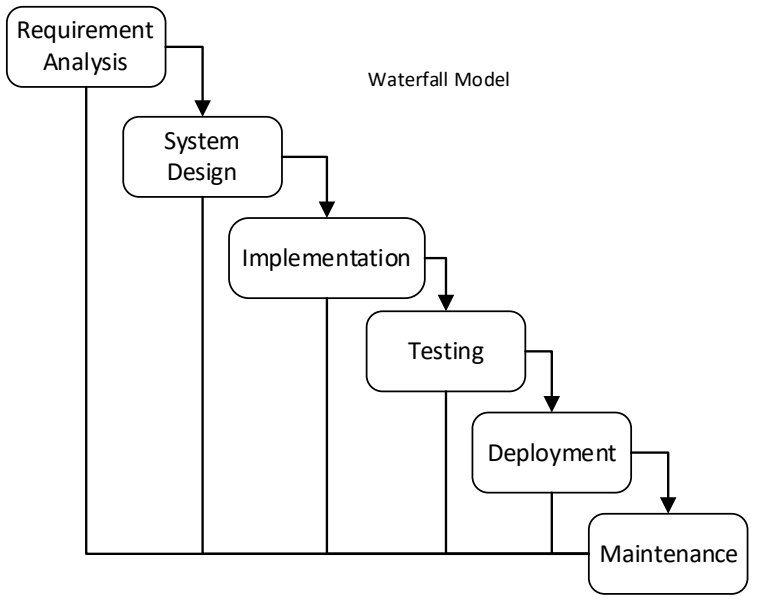

Figure 3: Waterfall Model

\section{Achievement Indicators}

Testing is basically an iterative process to find errors in a system that can be caused by several things, either software or hardware, as well as errors related to the design, implementation and specification determination processes. Correction of these errors is carried out continuously until the target output has been achieved properly. The following are the outcome indicators for this year's research:

1. Measurement of water $\mathrm{pH}$ and water conductivity can be carried out simultaneously, as a result of correcting measurement errors due to hardware interference.

2. $95 \%$ of the network connectivity test was successful (Repair of the Wi-Fi module from the previous research hardware).

3. The $\mathrm{pH}$ and $\mathrm{EC}$ value of water can be determined according to the volume given in milliliters.

4. Control and monitoring of water quality can be done via the TCP / IP network.

5. Embedded WEB went well

\section{RESUlts AND DisCUSSION}

\section{A. Hardware Development}

In this research, several hardware devices from previous studies have been developed to improve the overall system function. 


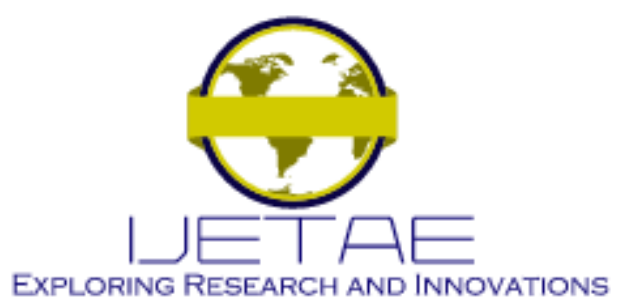

International Journal of Emerging Technology and Advanced Engineering Website: www.ijetae.com (E-ISSN 2250-2459, Scopus Indexed, ISO 9001:2008 Certified Journal, Volume 11, Issue 08, August 2021)

Added a 12VDC Power Supply module and motor driver to power the 12VDC dossing-pump and control it digitally. The addition of a Relay module for the purposes of setting when the $\mathrm{pH}$ and EC sensors are activated. In addition, an isolator module is also added to prevent leakage of current between the $\mathrm{pH}$ and EC sensors.

\section{B. Minimum Systems Module}

Minimum system as the main hardware in previous research has insufficient amount of program storage memory and Wi-Fi connection is often disconnected. Improvements to the power supply module and software library for the Wi-Fi module are also not able to provide maximum results. As an effort to improve the performance of $\mathrm{Wi}-\mathrm{Fi}$ connectivity and increase the size of programming memory, this research uses the minimum system module "MEGA + Wi-Fi R3 ATmega2560 + ESP8266", which is an Arduino Compatible Board with an ATmega2560 micro controller which is designed for the development of a minimum system equipped with capabilities. as a WEB server [15], WEB client and Wireless Access Point using the ESP8266 module [16]. The following are the specifications of the main hardware modules used in this study:

\begin{tabular}{|c|c|}
\hline \multicolumn{2}{|c|}{ Microcontroller: ATmega2560 } \\
\hline IC Wi-Fi & : ESP8266 \\
\hline \multicolumn{2}{|c|}{ USB-TTL converter : $\mathrm{CH} 340 \mathrm{G}$} \\
\hline \multicolumn{2}{|c|}{ Power Out $\quad: 5 \mathrm{~V}-800 \mathrm{~mA}$} \\
\hline \multicolumn{2}{|c|}{ Power IN. USB : 5V (500mA max.) } \\
\hline \multicolumn{2}{|c|}{ Power IN. VIN/DC Jack: 9-24V } \\
\hline \multicolumn{2}{|c|}{ Power Consumption : $5 \mathrm{~V} 800 \mathrm{~mA}$} \\
\hline $\mathrm{Wi}-\mathrm{Fi}$ & : Wi-Fi $802.11 \mathrm{~b} / \mathrm{g} / \mathrm{n} 2.4 \mathrm{GHz}$ \\
\hline \multicolumn{2}{|c|}{ Clock Frequency $: 16 \mathrm{MHz}$} \\
\hline \multicolumn{2}{|c|}{ Digital I/O $\quad: 54$} \\
\hline \multicolumn{2}{|c|}{ Analog I/O : 16} \\
\hline \multicolumn{2}{|c|}{ Memory Size $\quad: 256 \mathrm{~kb}$} \\
\hline \multicolumn{2}{|c|}{ Data RAM Type/Size $: 8 \mathrm{~Kb}$} \\
\hline \multicolumn{2}{|c|}{ Data ROM Type/Size $: 4 \mathrm{~Kb}$} \\
\hline \multicolumn{2}{|c|}{ Interface Type $\quad:$ serial $\backslash O T A$} \\
\hline \multicolumn{2}{|c|}{ Operating temperature $:-40 \mathrm{C}^{\circ} /+125 \mathrm{C}^{\circ}$} \\
\hline \multicolumn{2}{|c|}{ Length $\times$ Width: $53.361 \times 101.86 \mathrm{~mm}$} \\
\hline Antenna & : Build-inlexternal antenna \\
\hline
\end{tabular}

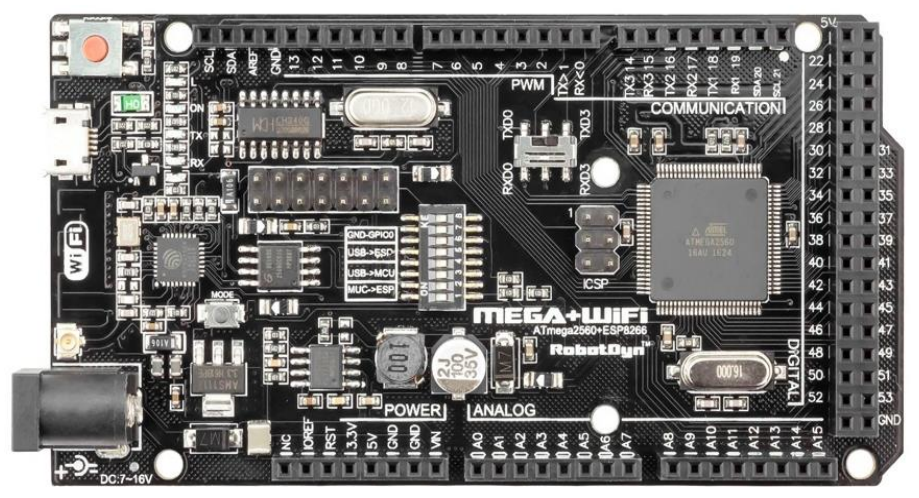

Figure 4: MEGA +Wi-Fi R3 ATmega2560+ESP8266 Minimum System

\section{Sensor Module}

To measure water $\mathrm{pH}$ and water conductivity (EC) requires 2 sensors connected to the Analog input pin, while measurements of water temperature and water level are connected to the Digital pin of the ATmega2560 microcontroller module. The sensor measurement results will be sent to the ESP8266 WEB Server module which can be accessed via the intranet network using a WEB browser [17].

The DS18B20 waterproof temperature sensor is used to measure the temperature of the water in the water reservoir of a hydroponic system. This sensor can be used in environments up to a temperature of $125 \mathrm{oC}$ and has a digital output (9-12bit) [9].

The water level sensor is needed to determine the water reserves in the water storage area of the hydroponic system. The workings of the HC-SR40 ultrasonic distance sensor is by measuring the travel time required for sound to bounce off objects in front of the sensor [12].

\section{System Architecture Design}

The image below is the hardware architecture of the embedded WEB application in a hydroponic system using the minimum system "MEGA + Wi-Fi R3 ATmega2560 + ESP8266". As shown in Figure 5, input data to determine the state of the quality and water reserve of the hydroponic system can be obtained from the temperature, $\mathrm{pH}, \mathrm{EC}$ and water level sensor modules. 


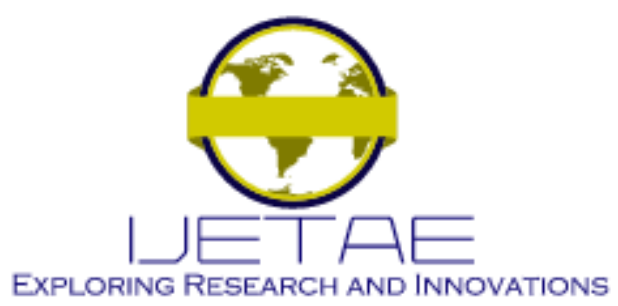

International Journal of Emerging Technology and Advanced Engineering

Website: www.ijetae.com (E-ISSN 2250-2459, Scopus Indexed, ISO 9001:2008 Certified Journal, Volume 11, Issue 08, August 2021)

The entire data is processed by ATmega2560 and forwarded to the ESP8266 via internal serial communication in the Minimum System as input data for the WEB Page which will be displayed by the WEB Server managed by the ESP8266 Module. The control function of $\mathrm{pH}$ and water nutrition can be done via the WEB page in the ESP8266 Module memory program. The data and commands are forwarded via internal serial communication to the ATmega2650 Module to drive the Dossing-pump pH-Up, pH-Down, A-Mix nutrients and B-Mix nutrients.

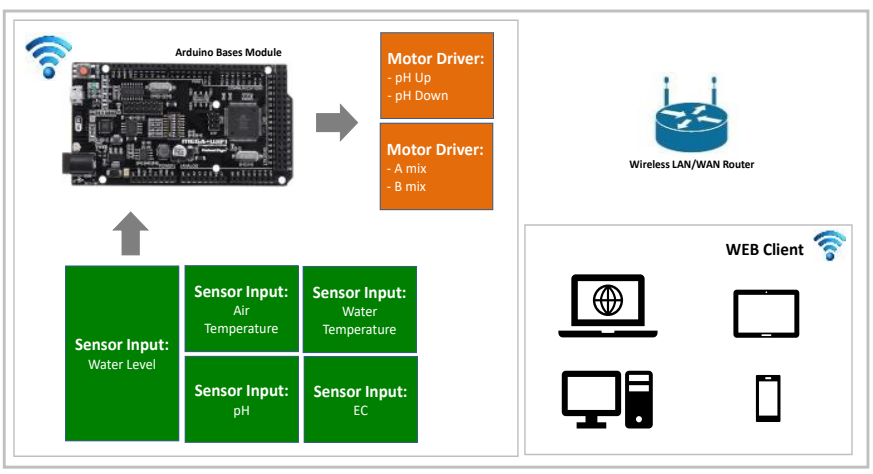

Figure 5: System Architecture

The embedded WEB application in the minimum system module "MEGA + Wi-Fi R3 ATmega2560 + ESP8266" can be accessed using a WEB browser via a Wireless LAN network by activating the WEB Server mode managed by the ESP8266 Module. Thus, the Embedded WEB application can be accessed at any time by client computers from a TCP/IP network that is in one network address through an Access Point.

\section{E. Hardware Implementation}

In previous research, the $\mathrm{pH}$ sensor module can be activated together with the conductivity sensor by adding an isolator module to the input / output intermediate module of the sensor to prevent electrical interference [1] as shown in the red box in Figure 6. By replacing the microcontroller module with "MEGA + Wi-Fi R3 ATmega2560 + ESP8266", the TCP/IP network connection problems via Wi-Fi can be resolved properly, and a dosingpump module to adjust $\mathrm{pH}$ and water nutrition can also be added.

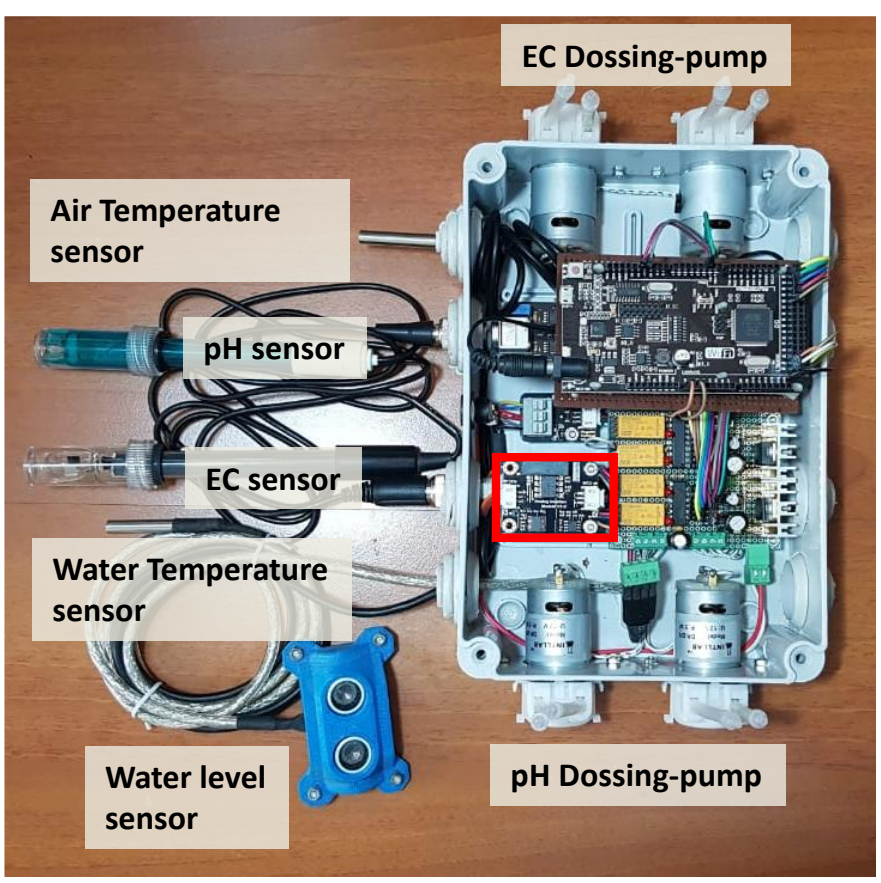

Figure 6: Minimum Hydroponics System

\section{F. Software Implementation}

User Interface design of the embedded Web Application to monitor water quality conditions and adjust $\mathrm{pH}$ and water conductivity remotely via a TCP/IP network. The design of the Web page for observation and control of water quality can be seen in Figure 7 and Figure 8. Monitoring Mode is used to observe water quality, while Set Water Quality Mode is used to change the $\mathrm{pH}$ value or nutrient content in water. When the OK button is pressed, the dosing-pump will turn on and pump liquid from the $\mathrm{pH}$ or nutrient tube to the water in the hydroponic system pipe.

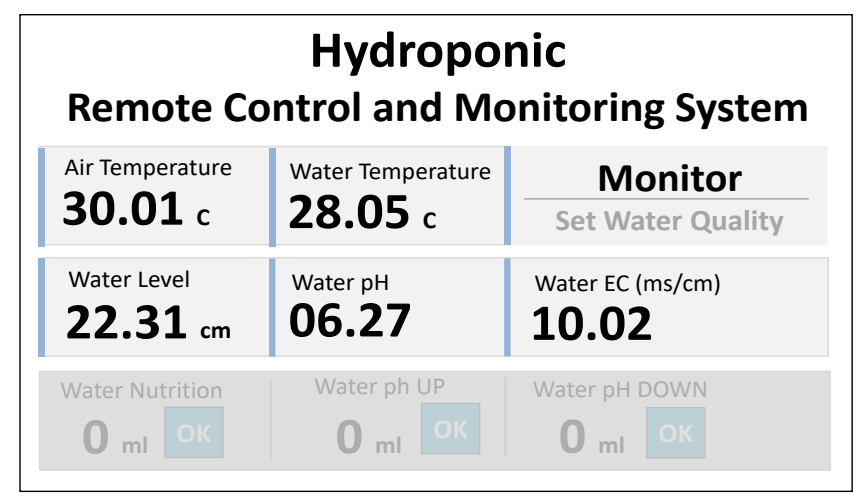

Figure 7: Webpage Monitoring Design 


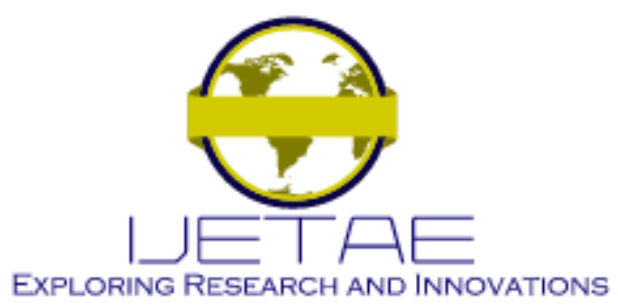

International Journal of Emerging Technology and Advanced Engineering

Website: www.ijetae.com (E-ISSN 2250-2459, Scopus Indexed, ISO 9001:2008 Certified Journal, Volume 11, Issue 08, August 2021)

To enter Control mode, it can be done by pressing the Set Water Quality box, so that the input boxes for Water Nutrition, $\mathrm{pH}-\mathrm{Up}$ and $\mathrm{pH}-$ Down become active as shown in Figure 5.5. The input data that can be provided are integers. If you want to return to Observation mode, you can do this by pressing the Monitor box.

\begin{tabular}{|c|c|c|}
\hline \multicolumn{3}{|c|}{$\begin{array}{l}\text { Hydroponic } \\
\text { Remote Control and Monitoring System }\end{array}$} \\
\hline $\begin{array}{l}\text { Air Temperature } \\
30.01 \text { c }\end{array}$ & $\begin{array}{l}\text { Water Temperature } \\
\mathbf{2 8 . 0 5}\end{array}$ & $\begin{array}{c}\text { Monitor } \\
\text { Set Water Quality }\end{array}$ \\
\hline $\begin{array}{l}\text { Water Level } \\
22.31 \mathrm{~cm}\end{array}$ & $\begin{array}{l}\text { Water } \mathrm{pH} \\
06.27\end{array}$ & $\begin{array}{l}\text { Water } E C(\mathrm{~ms} / \mathrm{cm}) \\
\mathbf{1 0 . 0 2}\end{array}$ \\
\hline Water Nutrition & Water ph UP & Water pH DOWN \\
\hline $80 \mathrm{ml}$ ОК & $10 \mathrm{ml}$ & $20 \mathrm{ml}$ OK \\
\hline
\end{tabular}

Figure 8: Webpage Control Design

\section{G. Test Results}

The following will explain the results of the test access to the embedded WEB application, connectivity tests, $\mathrm{pH}$ and EC measurements carried out simultaneously, the observation function of the hydroponic system, and the function of controlling $\mathrm{pH}$ and water nutrition.

Access to the Embedded Web Application: When the client computer accesses the Web Server in the minimum system module "MEGA + Wi-Fi R3 ATmega2560 + ESP8266" using a Web browser application, the default WEB page for Monitoring mode will be displayed as shown in Figure 5.6. From the test results of access to the Hydroponic Remote Control and Monitoring Web site using mobile devices such as laptops and smartphones, information regarding air temperature, water temperature, water level, water $\mathrm{pH}$ and water EC is updated periodically every 5 seconds.

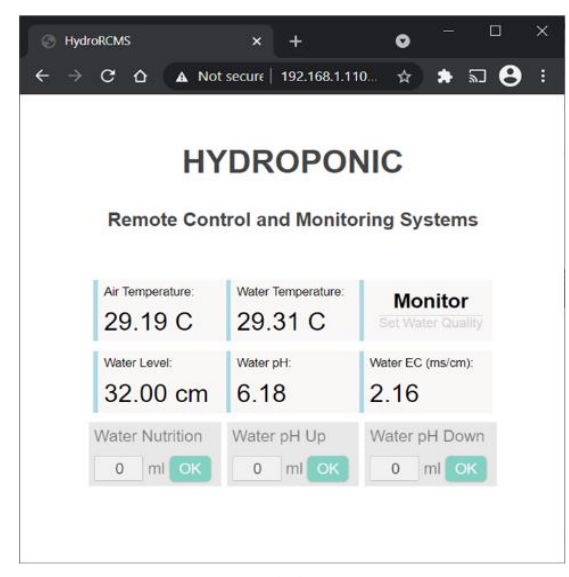

(a)

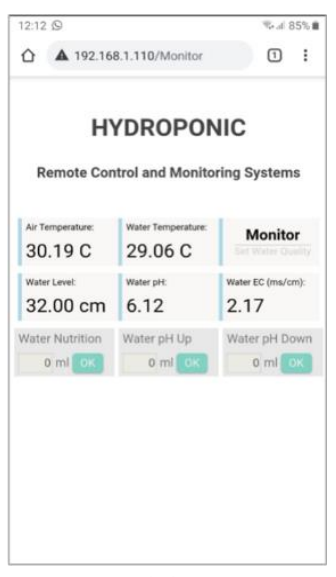

(b)
Figure 9: Access to the Hydroponic RCMS Web Site

Before the Hydroponic Remote Control and Monitoring Website can be accessed via the TCP / IP network, the Web Server application module in the ESP8266 hardware module needs to be activated first. After the Boot-Up process and access to the TCP / IP network is complete, the system will immediately activate the HTTP server and detect all installed sensor modules. From Figure 9 it can be seen that the machine log output reads "HTTP server started" which shows that the Web Server is ready and working properly.

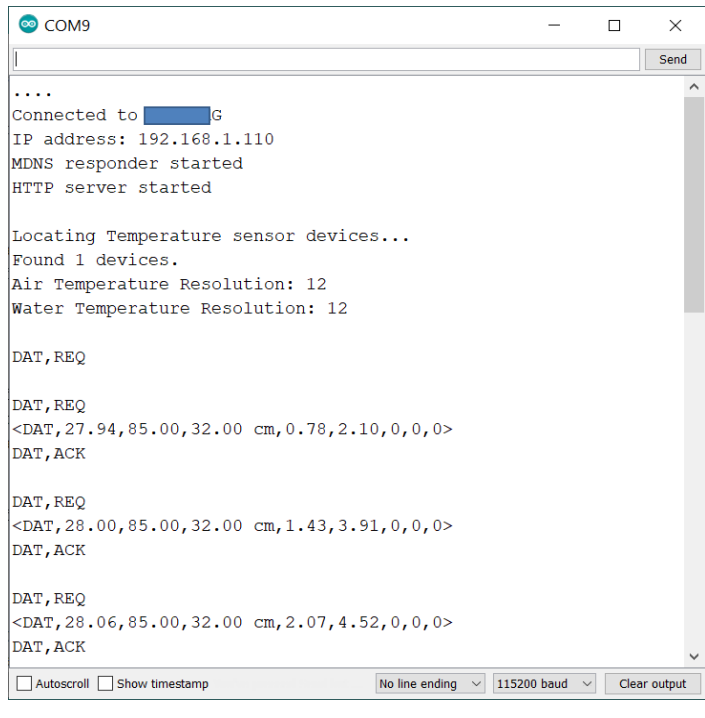

Figure 9: Embedded WEB Server 


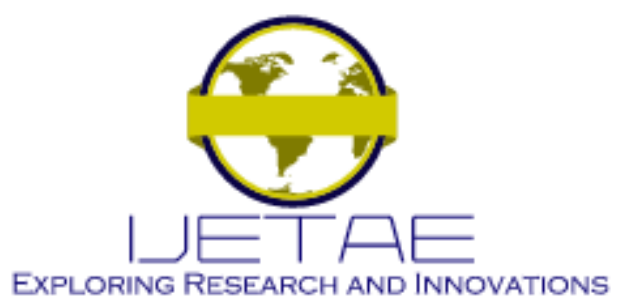

International Journal of Emerging Technology and Advanced Engineering

Website: www.ijetae.com (E-ISSN 2250-2459, Scopus Indexed, ISO 9001:2008 Certified Journal, Volume 11, Issue 08, August 2021)

Connectivity Test: In previous studies, network connectivity is one of the causes of failure to display measurement results. To see the performance of the Wi-Fi module that is in the minimum system "MEGA + Wi-Fi R3 ATmega2560 + ESP8266", a connectivity test is carried out using the PING test standard. The implementation of the

Following are the results of testing the $\mathrm{pH}$ and $\mathrm{EC}$ water observations in sequence: (a) EC sensor in water; (b) EC sensor outside water; (c) The EC sensor is put back into the water. It appears that the $\mathrm{pH}$ value does not change significantly, this proves that the EC sensor can be activated simultaneously with the $\mathrm{pH}$ sensor. PING test can be seen in Figure 10, where there are 1000 PING packets sent to the Web Server continuously every second.

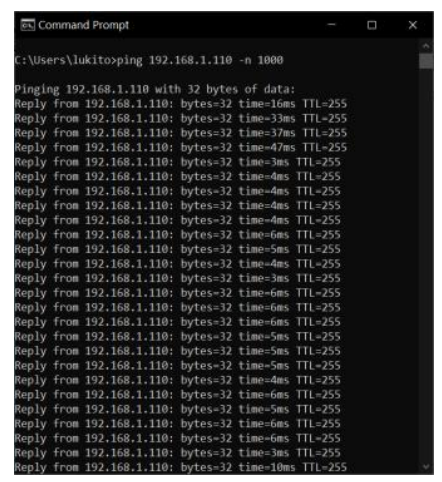

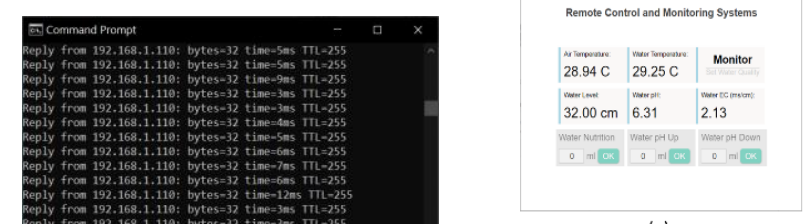

(a)

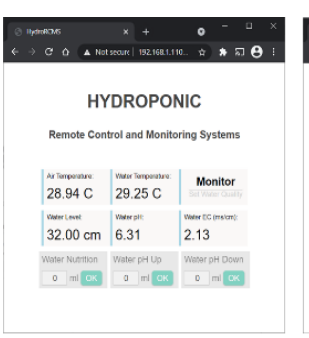

Figure 12: Water pH and EC measurement

Hydroponic System Observation Function: Observation of $\mathrm{pH}, \mathrm{EC}$, height and water temperature, and air temperature will be updated every 5 seconds and can be done online 24 hours x 7 days via a browser on every computer or other mobile device such as smartphones and tablets. With the TCP/IP network, the monitoring function can be done from a remote location.

From the test results, it was found that the packet loss was 1\%. Time diagram Figure 5.9 shows the average Round Trip Time value is $9.03 \mathrm{~ms}$, the minimum is $2 \mathrm{~ms}$, and the maximum is 255. The WEB Server can be accessed and used properly to control and monitor water quality from the Hydroponic system.

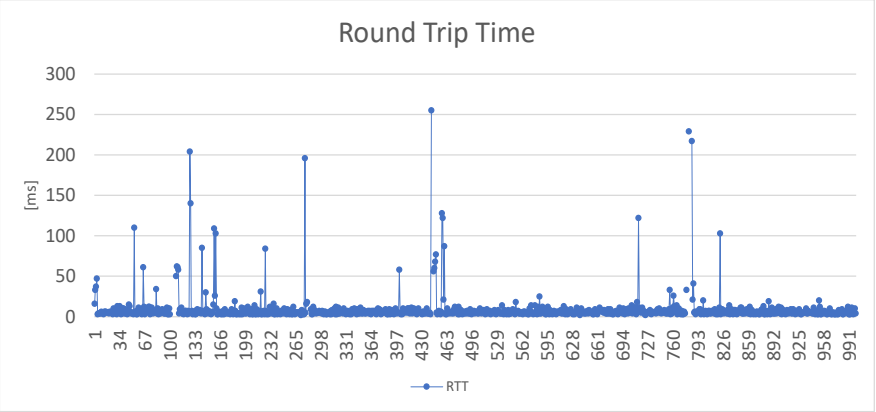

Figure 11: Ping Test Results

Water $\mathrm{pH}$ and EC measurement: By adding an isolator module to the EC sensor, the Grounding and Positive reference points of the EC sensor will not become one with the other modules. The current flowing between the 2 poles of the EC sensor through the water has no impact on the measurements made by the $\mathrm{pH}$ sensor.

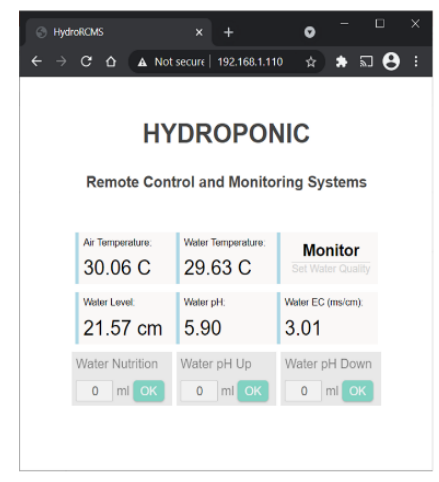

(a)

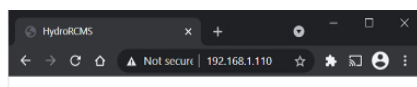

HYDROPONIC

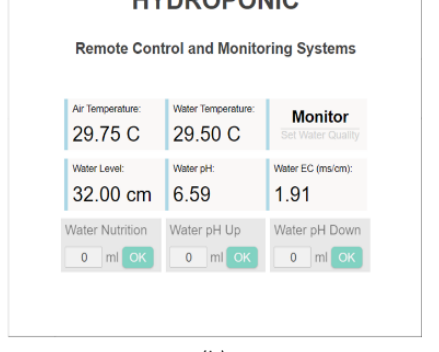

(b)
Figure 13: Hydroponic System Observation Menu

PH Control and Water Nutrition Function: To keep hydroponic plants from getting adequate and well-absorbed nutrient supplies, the $\mathrm{pH}$ value of water must be maintained at a certain level according to plant characteristics. The amount of nutrients also needs to be maintained so that plants can grow properly. From the example in Figure 5.12 (a) it can be seen that the water $\mathrm{pH}$ condition needs to be lowered to below 6.5 by adding pH-Down liquid. 


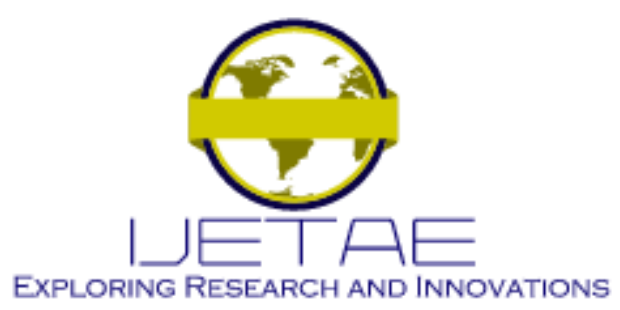

International Journal of Emerging Technology and Advanced Engineering

Website: www.ijetae.com (E-ISSN 2250-2459, Scopus Indexed, ISO 9001:2008 Certified Journal, Volume 11, Issue 08, August 2021)

After entering the liquid volume data and pressing the "OK" button, the liquid from the pH-Down tube will be transferred to a water reservoir. After the liquid dissolves evenly in the water, it can be seen in Figure 5.12 (b) that the $\mathrm{pH}$ value of the water drops. The EC value also increases, because in the $\mathrm{pH}-\mathrm{Up}$ and $\mathrm{pH}-$ Down fluids there are also minerals that are also needed by hydroponic plants as nutrients.

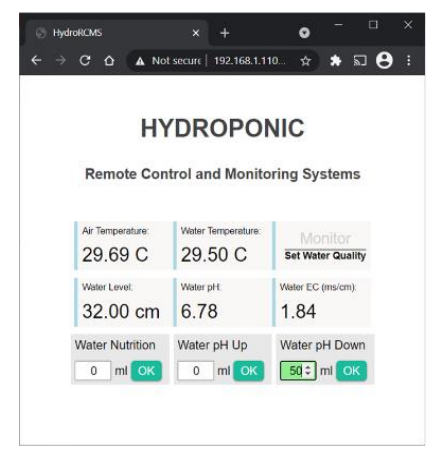

(a)

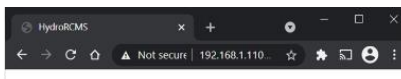

HYDROPONIC

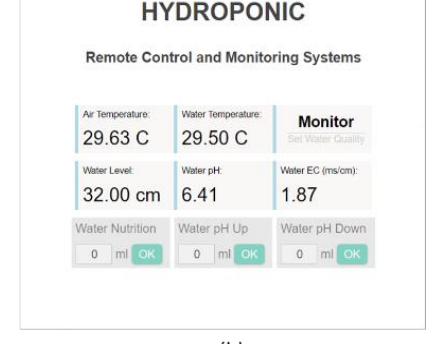

(b)
Figure 14: pH Control and Water Nutrition Menu

\section{CONCLUSION}

The following are the conclusions from the research results:

1. When the conductivity sensor is activated, the results of water $\mathrm{pH}$ and water $\mathrm{EC}$ measurements can run well and provide the correct value so that the control process of water $\mathrm{pH}$ and water nutrition can be carried out properly.

2. The Wi-Fi module of the minimum system has a good performance with a packet loss value of $1 \%$, and access to the WEB can be done at any time.

3. Remote control function provides flexibility in setting the $\mathrm{pH}$ value of water and water nutrients for the maintenance of hydroponic plants

\section{RECOMMENDATIONS FOR FURTHER RESEARCH}

The recommendation for the next development of this system are:

1. Need the addition of Grow-LED to provide maximum hydroponic yields.

2. Dossing-pump accuracy also determines the accuracy of $\mathrm{pH}$ and nutrient settings for hydroponic plants, so it is necessary to provide parameters for offset adjustments.

\section{REFERENCES}

[1] R. B. Lukito and C. Lukito, "Development of IoT at hydroponic system using raspberry $\mathrm{Pi}$," Telkomnika (Telecommunication Comput. Electron. Control., vol. 17, no. 2, 2019, doi: 10.12928/TELKOMNIKA.V17I2.9265.

[2] E. B. Abbade, "Availability, access and utilization," World J. Sci. Technol. Sustain. Dev., vol. 14, no. 4, pp. 322-335, 2017, doi: 10.1108/wjstsd-05-2016-0033.

[3] J. Russell, V. Flood, H. Yeatman, and P. Mitchell, "Food Security in Older Australians," J. Nutr. Educ. Behav., vol. 43, no. 2, pp. 1-4, 2011, doi: 10.1016/j.jneb.2010.12.007.

[4] D. J. Shaw and D. J. Shaw, "World Food Summit, 1996," World Food Secur., vol. 1, pp. 347-360, 2007, doi 10.1057/9780230589780_35.

[5] A. Grigas, A. Kemzūraitè, and D. Steponavičius, "Hydroponic Devices for Green Fodder Production: a Review," Rural Dev. 2019, vol. 2019, no. 1, pp. 21-27, 2020, doi: 10.15544/rd.2019.003.

[6] HydroPros, "Hydroponic Systems \& What's Right For You," 2019. https://hydropros.com/blogs/growers-corner/6-types-hydroponicsystems.

[7] Arduino, "What is Arduino?," Arduino, 2020 https://www.arduino.cc/en/guide/introduction.

[8] Arduino Project Hub, "Getting Started with Arduino products," Arduino, 2020. https://www.arduino.cc/en/Guide.

[9] Maxim integrated, "DS18B20 Programmable Resolution 1," vol. 92, pp. 1-20, 2019.

[10] DFRobot, "PH meter SKU SEN0161," 2020, [Online]. Available: https://wiki.dfrobot.com/PH_meter_SKU__SEN0161_.

[11] DFRobot, "DFR0300 Gravity: Analog Electrical Conductivity Sensor Meter V2," 2020 https://wiki.dfrobot.com/Gravity__Analog_Electrical_Conductivity_ Sensor__Meter_V2_K\%3D1_SKU_DFR0300.

[12] Elijah J. Morgan, "HC SR04 Ultrasonic Ranging Sensor Module," Eval. Tec. Sens., p. Nov. 16 2014, 2014, [Online]. Available: https://www.pcbway.com/blog/News/New_product_in_gift_shop_ HC_SR04_Ultrasonic_Ranging_Sensor_Module.html.

[13] KT-elektronic, "Ultraschall Messmodul HC-SR04," pp. 4-6, 2012.

[14] R. S. Pressman, Software Engineering: A Practitioner's Approach, 7th ed. New York: The McGraw-Hill, 2014.

[15] RobotDyn, "MEGA+WiFi R3 ATmega2560+ESP8266, flash 32MB, USB-TTL CH340G, Micro-USB," 2020. https://robotdyn.com/mega-wifi-r3-atmega2560-esp8266-flash32mb-usb-ttl-ch340g-micro-usb.html (accessed Dec. 12, 2021).

[16] DFRobot, "FireBeetle ESP8266 IoT Microcontroller," 2020. https://wiki.dfrobot.com/FireBeetle_ESP8266_IOT_Microcontroller _SKU__DFR0489 (accessed Mar. 31, 2021).

[17] Espressif Systems, "ESP8266 Wi-Fi MCU I," 2020 https://www.espressif.com/en/products/socs/esp8266 (accessed Aug. 26, 2020). 